\title{
SUMMER 1988
}

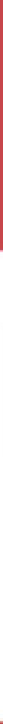

\section{DISCUSSION}

Holland Hunter : Soviet Agriculture with and without Collectivization, 1928-1940

Lynne Viola : Back on the Economic Front of Collectivization or Soviet Agriculture without Soviet Power

Holland Hunter : Reply to Viola or toward Historical Analysis with Fuller Understanding

\section{ARTICLES}

Edward J. Brown : The Symbolist Contamination of Gork'ii's “Realistic” Style Aileen Kelly : Dostoevskii and the Divided Conscience

Aleksey E. Levin : Expedient Catastrophe: A Reconsideration of the 1929 Crisis at the Soviet Academy of Science

Helena Goscilio : Tat'iana Tolstaia's “Dome of Many-Coloured Glass”: The World Refracted through Multiple Perspectives

\section{NOTES AND COMMENTS}

Jean Ispa : Soviet Immigrant Mothers' Perceptions Regarding the First Childbearing Year: The 1950s and the 1970s

\section{REVIEW ESSAYS}

Julia Brun-Zejmis : Polish Communists Speak

Theodore Taranovski : Nobility in the Russian Empire: Some Problems of Definition and Interpretation 


\section{EDITOR}

Sidney Monas

\begin{tabular}{|c|c|}
\hline BOOK REVIEW EDITOR & Daniel T. Orlovsky \\
\hline ASSOCIATE EDITOR & Mary Jo Powell \\
\hline ASSISTANT EDITORS & $\begin{array}{l}\text { Shoshanah DiETz } \\
\text { Joseph LiRo }\end{array}$ \\
\hline EDITORIAL ASSISTANT & Bejou Merry \\
\hline
\end{tabular}

HONORARY EDITORS: Frederick Barghoorn • Vera S. Dunham • John N. Hazard • Demitri B. Shimkin • René Wellek

EDITORIAL BOARD: Kendall E. Bailes, University of California, Irvine - George W. Breslauer, University of California, Berkeley • Malcolm Hamrick Brown, Indiana University • Istvan Deak, Columbia University • Caryl Emerson, Princeton University • Maurice Friedberg, University of Illinois, Urbana-Champaign - Keith Hitchins, University of Illinois, UrbanaChampaign - James Michael Holquist, Yale University - D. Barton Johnson, University of California, Santa Barbara • Robert A. Maguire, Columbia University • Hans Rogger, University of California, Los Angeles - William G. Rosenberg, University of Michigan - H. Gordon Skilling, University of Toronto $\bullet$ Richard Stites, Georgetown University • Victor Terras, Brown University • Alexander Vucinich, University of Pennsylvania • Piotr S. Wandycz, Yale University

CONSULTANTS ON SOVIET AND EAST EUROPEAN BOOKS: George Barany, University of Denver • Alexandra L. Batalden, Arizona State University • John D. Bell, University of Maryland, Baltimore County • Imre Boba, University of Washington • Marianna Tax Choldin, University of Illinois, Urbana-Champaign - F. W. Galan, Georgia Institute of Technology • Adam A. Hetnal, Vanderbilt University - Keith Hitchins, University of Illinois, UrbanaChampaign - Charles Jelavich, Indiana University • Owen V. Johnson, Indiana University • Andrejs Plakans, lowa State University • Gale Stokes, Rice University • Orest Subtelny, York University, Ontario • Ronald Grigor Suny, University of Michigan

The editors assume no responsibility for statements of fact or opinion made by contributors.

The Slavic Review (ISSN 0037-6779) (formerly The American Slavic and East European Review) is published quarterly by the American Association for the Advancement of Slavic Studies, Inc., and is sent to all Association members. Members also receive the AAASS Newsletter. Membership is open to individuals interested in the advancement of Slavic studies (including study of the non-Slavic peoples of Eastern Europe and the USSR), and applications for membership are accepted by the national headquarters of the AAASS, 128 Encina Commons, Stanford University, Stanford, CA 94305; (415) 723-9668.

Membership dues: salary $\$ 10,000$ to $\$ 19,999-\$ 30.00 ; \$ 20,000$ to $\$ 29,999-\$ 35.00 ; \$ 30,000$ to $\$ 39,999-\$ 40.00 ; \$ 40,000$ to $\$ 49,999-\$ 45.00$; over $\$ 50,000-\$ 50.00$. Joint members with one subscription to the Slavic Review, add $\$ 10.00$ to dues of higher paid member. Dues for students, emeriti, or those with salaries under $\$ 10,000$ are $\$ 20.00$. New Affiliate (Newsletter only): $\$ 15.00$. Subscriptions without membership are $\$ 45.00$. Single current issues and back issues to subscribers are $\$ 15.00$; back issues for members are $\$ 10.00$ each. Correspondence regarding membership, subscriptions, changes of address, or items for the Newsletter should be sent to the AAASS headquarters in Stanford. Advertising inquiries should also be directed to the AAASS office.

Articles, books for review, and correspondence concerning editorial matters should be sent to the Slavic Review, P.O. Box 8180, University of Texas, Austin, Texas 78713; (512) 471-5898. Building address is Geography 106B. Technical requirements for manuscript submissions are given on the inside back cover.

Published by the American Association for the Advancement of Slavic Studies, Inc. Composition by G\&S Typesetters, Austin, Texas. Printed by Heffernan Press, Inc., Worcester, Massachusetts. Second-class postage paid at Palo Alto, CA and additional mailing office. POSTMASTER: Send address changes to Slavic Review, c/o AAASS, 128 Encina Commons, Stanford University, Stanford, CA 94305.

Copyright (C) 1988 by the American Association for the Advancement of Slavic Studies, Inc. 


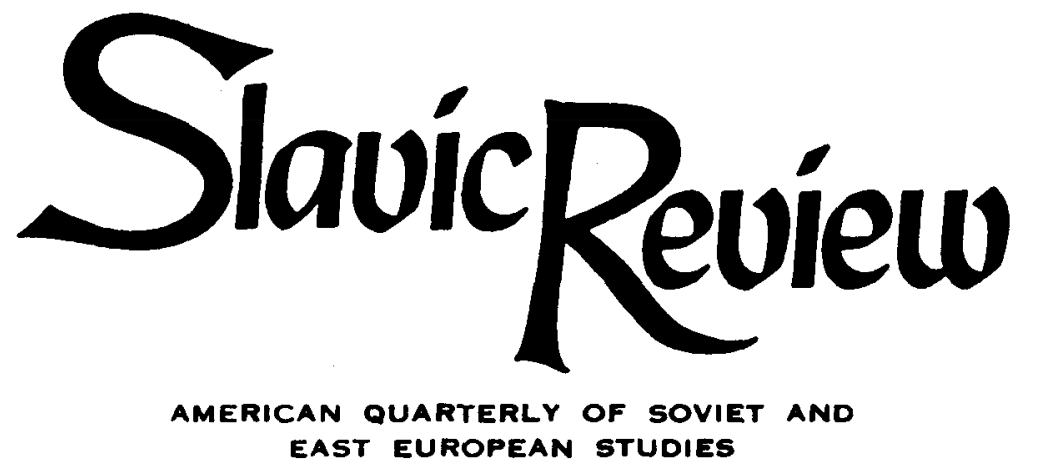

VOLUME 47 NUMBER 2 • SUMMER 1988

\section{DISCUSSION}

Soviet Agriculture with and without Collectivization, 1928-1940 HOLLAND HUNTER

Back on the Economic Front of Collectivization or Soviet Agriculture without Soviet Power

LYNNE VIOLA

Reply to Viola or toward Historical Analysis with Fuller Understanding HOLLAND HUNTER

\section{ARTICLES}

The Symbolist Contamination of Gork'ii's "Realistic" Style EDWARD J. BROWN

Dostoevskii and the Divided Conscience

AILEEN KELLY

Expedient Catastrophe: A Reconsideration of the 1929 Crisis at the Soviet Academy of Science

ALEKSEY E. LEVIN

Tat'iana Tolstaia's "Dome of Many-Coloured Glass": The World

Refracted through Multiple Perspectives

HELENA GOSCILIO 


\section{NOTES AND COMMENTS}

Soviet Immigrant Mothers' Perceptions Regarding the First Childbearing Year: The 1950s and the 1970s 291

JEAN ISPA

\section{REVIEW ESSAYS}

Polish Communists Speak

JULIA BRUN-ZEJMIS

Nobility in the Russian Empire: Some Problems of Definition and Interpretation

THEODORE TARANOVSKI

\section{REVIEWS}

Mikhail Heller and Aleksandr M. Nekrich, Utopia in Power: The History of the Soviet Union from 1917 to the Present (Alexander Dallin)

Ewa M. Thompson, Understanding Russia: The Holy Fool in Russian Culture (Nancy Shields Kollman)

Janet Martin, Treasure of the Land of Darkness: The Fur Trade and Its Significance for Medieval Russia (David H. Kaiser)

E. A. Rybina, Inozemnye dvory v Novgorode XII-XVII vv. (Henrik Birnbaum)

Jo Ann Ruckman, The Moscow Business Elite: A Social and Cultural Portrait of Two Generations, 1840-1905 (Thomas C. Owen)

Derek Offord, The Russian Revolutionary Movement in the 1880s (Deborah L. Pearl)

I. S. Belliutsin, Description of the Clergy in Rural Russia: The Memoirs of a Nineteenth-Century Parish Priest, Gregory L. Freeze, trans. (Dimitry V. Pospielovsky)

Walther Kirchner, Die deutsche Industrie und die industrialisierung Russlands 1815-1914 (Roderick E. McGrew)

Dietrich Geyer, Russian Imperialism: The Interaction of Domestic and Foreign Policy 1860-1914 (Theodore H. Von Laue)

G. P. Wells, ed., H. G. Wells in Love: Postscript to an Experiment in Autobiography, Anthony West, H. G. Wells: Aspects of a Life (Mikhail Agursky)

Hugh Thomas, Armed Truce: The Beginnings of the Cold War 1945-46 (Woodford McClellan)

Carol A. Leadenham, comp., Guide to the Collections in the Hoover Institution Archives Relating to Imperial Russia, the Russian Revolutions and Civil War, and the First Emigration (Edward Kasinec) 
Russia in the Twentieth Century: The Catalog of the Bakhmeteff Archive of Russian and East European History and Culture: The Rare Book and Manuscript Library, Columbia University (Edward Kasinec)

Robert English and Jonathan J. Halperin, The Other Side: How Soviets and Americans Perceive Each Other (Paul Hollander)

Peter Savigear, Cold War or Détente in the 1980s: The International Politics of American-Soviet Relations (Paul Michael Kozar)

Voitech Mastny, Helsinki, Human Rights, and European Security: Analysis and Documentation (William E. Griffith)

Ellen Comisso and Laura D'Andrea Tyson, eds., Power, Purpose, and Collective Choice: Economic Strategy in Socialist States (Heidi Kroll)

Leslie Holmes, Politics in the Communist World (Thomas F. Remington)

Stephen Fortesque, The Communist Party and Soviet Science (Linda Lubrano)

William C. Green, Soviet Nuclear Weapons Policy: A Research and Bibliographic Guide (Matthew Evangelista)

Ger P. van den Berg, Organisation und Arbeitsweise der sowjetischen regierung Osteuropa und der internationale Kommunismus (Derek Watson)

Alexei Mahmoudov, The Soviet Oil and Natural Gas Industries (Problems of Reserve Estimation) (Albina Tretyakova)

Craig ZumBrunnen and Jeffrey P. Osleeb, The Soviet Iron and Steel Industry (Anne L. Jablonski)

János Kornai, Contradiction and Dilemmas: Studies on Socialist Economy and Society (Benjamin Ward)

Bruno Schönfelder, Ökonomisches Risiko und Versicherung in sozialistischen Volkswirtschaften: Am Beispiel der UdSSR und der $D D R$ unter Einbeziehung der Sozialversicherung und unter Berückichtigung der Versicherungstheorie (John Parsons)

Robert Deutsch, The Food Revolution in the Soviet Union and Eastern Europe (Karen Brooks)

Ellen Jones and Fred W. Grupp, Modernization, Value Change and Fertility in the Soviet Union (Mary Kilbourne Matossian)

Gerhard Simon, Nationalismus und Nationalitätenpolitik in der Sowjetunion: Von der totalitaren Diktaturzur nachstalinschen Gesellschaft (James Critchlow)

Lorna Bourdeaux and Michael Bourdeaux, Ten Growing Soviet Churches (Dennis J. Dunn)

Hans-Hermann Hohmann and Heinrich Vogel, eds., Osteuropas Wirschaftsprobleme und die Ost-West-Beziehungen (Andrzej Korbonski) 
Charles J. Bukowski and Mark A. Cichock, eds., Prospects for Change in Socialist Systems: Challenges and Responses (Raymond Taras)

Stephen A. Garrett, From Potsdam to Poland: American Policy toward Eastern Europe (Andrew A. Michta)

Eino Ketola, Kansalliseen kansanvaltaan: Suomen itenäisyys, sosialidemokraatit Ja Venäjän vallankumous 1917 (Anthony Upton)

Karolina Targosz, Jana Sobieskiego nauki i peregrynacje (Adam A. Hetnal)

Aleksander Gieysztor, Jerzy Maternicki, and Henryk Samsonowicz, eds., Historycy warszawscy ostatnich dwóch stuleci; Stanisław Sławomir Nicieja, Adam Próchnik: Historyk-Polityk-Publicysta (Adam A. Hetnal)

Jan Křen, Václav Kural and Detlef Brandes, Integration oder Ausgrenzung: Deutsche und Tschechen 1890-1945 (Yeshayahu A. Jelinek)

František Tomek, Z dejín revolučného odborového hnutia na Slovensku v rokoch 1944-1948 (Michael J. Kopanic, Jr.)

Stefan Malfèr, ed., Die Protokolle des österreichischen Ministerrates 1848-1867. Abteilung 5, Band 3: Die Ministerien Erzherzog Rainer und Mensdorf, 5. November 1861-6. Mai 1862 (Lawrence Sondhaus)

Marianna D. Birnbaum, Humanists in a Shattered World: Croatian and Hungarian Latinity in the Sixteenth Century (Ante Kadić)

Péter Hanák, Jászi oszkár dunai patriotizmusa (Gabor Vermes) 360

Charles Gati, Hungary and the Soviet Bloc (Ivan Volgyes)

Radoš Ljušić, Kneževina Srbija (1830-1839) (David MacKenzie)

Hans Knoll, Jugoslawien in Strategie und Politik der Alliierten 1940-1943 (Gerhard L. Weinberg)

Karl-Heinz Schlapp, Wirtschaft und Besatzung in Serbien 1941-1944:

Ein Beitrag zur nationalsozialistischen Wirtschaftspolitik in Südosteuropa (Jozo Tomasevich)

Johann Böhm, Das nationalsozialistische Deutschland und die deutsche Volksgruppe in Rumänien 1936-1944: Das Verhältnis der deutschen Volksgruppe zum dritten Reich und zum rumänischen Staat sowie der interne Widerstreit zwischen den politischen Gruppen (Keith Hitchins)

Liubomir Atanasov Panaiotov and Iordan Nikolov Shopov, comps., Osvoboditelnoto dvizhenie v Makedoniia i Odrinsko: Spomeni $i$ materiali (Duncan M. Perry)

Stoicho Grŭncharov, Politicheskite sili i monarkhicheskiiat institut v Bülgariia 1886-1894 (Duncan M. Perry) 
Joseph Frank, Dostoevsky: The Stir of Liberation 1860-1865 (Gary Cox)

Milton Ehre, Isaac Babel (Efraim R. Sicher)

John E. Malmstad, ed., Andrey Bely: Spirit of Symbolism (Peter I. Barta)

Rostislav Shul'ts, Pushkin i knidskii mif (Savely Senderovich)

Janet G. Tucker, Innokentij Annenskij and the Acemist Doctrine (Michael B. Kreps)

Juliette R. Stapanian, Mayakovsky's Cubo-Futurist Vision (Edward J. Brown)

Antonín Měšt'an, Česká literatura 1785-1985 (Zdenek Salzmann)

Wolfgang Kasack, Science-Fiction in Osteuropa: Beiträge zur russichen, polnischen und tschechischen phantastischen Literatur (Frank Dietz)

Ronelle Alexander, The Structure of Vasco Popa's Poetry (Vladimir Miličić)

Wilhelm von Timroth, Russian and Soviet Sociolinguistics and Taboo Varieties of the Russian Language (Argot, Jargon, Slang and "Mat") (Vladimir Kozlovskii)

Celia Hawkesworth, Colloquial Serbo-Croat (John S. Kolsti)

Janusz Cegiełła, Dziecko szczȩseia: Aleksander Tansman i jego czasy (William Smialek)

Ronald Holloway, The Bulgarian Cinema (F. W. Galan)

Solanus: International Journal for Russian and East European

Bibliographic, Library, and Publishing Studies (Jeffrey Brooks) 